\title{
The Causes of Variation Orders and Their Effects on Cost and Time of Projects in Sulaimani Governorate
}

\author{
Karukh Hassan \\ Civil Engineering \\ College of Engineering \\ University of Sulaimani \\ Sulaimani, Iraq \\ Karukh.mhamad@univsul.edu.iq \\ Basira Majeed \\ Administration and Economic \\ College of Administration and Economic \\ University of Sulaimani \\ Sulaimani, Iraq \\ Basira.Najm@univsul.edu.iq
}

Civil Engineering

College of Engineering

University of Cihan- Erbil

Erbil, Iraq

Noori.ali@cihanuniversity.edu.iq

\begin{tabular}{l} 
Article Info \\
Volume $5-$ Issue $\mathbf{1}-$ \\
June 2020 \\
DOI: \\
10.24017/science.2020.1.16 \\
Article history: \\
Received:24 March 2020 \\
Accepted:14 June 2020 \\
\hline Keywords: \\
Causes of variation order, \\
Cost overrun, Construction \\
projects, Effect of variation \\
order, Time overrun, \\
Variation orders.
\end{tabular}

\begin{abstract}
Variation orders are a permanent phenomenon in the construction of projects and industries around the world, and particularly in the province of Sulaymaniyah. Where construction industries suffer from variation orders. It includes an amendment of the initial scope of work as in the awarded contract. This study analyses the causes of variation orders and their effects on cost and time of projects in Sulaimani governorate. This study involves a questionnaire survey to selected 36 causes and 10 effects of variation orders from the perspective of owner, design consultant, and contractors. A total of 223 completed questionnaire sets were returned out of 270 questionnaires distributed among the practitioners. Then the data was analyzed statistically. Also, 40 projects at different construction sectors that constructed during 2007-2013 were investigated by calculating cost and time overrun because of variation orders. The results showed that in Sulaimani governorate the most effective causes of variation orders are owner's financial problems, preparing typical design for different districts, errors and omission in design, desired profitability of contractor and lack of adequate or appropriate site before design stage to construct of project. On the other hand of impacts of variations, the study discovered that top five effects of variation orders on the projects are: schedule overrun, cost overrun, productivity degradation, dispute between contract stockholders and payment delay. Also, all projects affected by cost and time overruns at average of 20 percent of cost and 65.4 percent of time of project.
\end{abstract}

Copyright (C) 2020 Kurdistan Journal of Applied Research. 


\section{INTRODUCTION}

Construction projects are involved of more complicated small activities and different stakeholder's involvement that make them complex. The difficulty of construction activities indicated that is seldom to being executed an entire project lacking of variations to the design or to the process of construction. The most significant problem that occur during construction management process is variation orders. Changes or variations as "deletions, additions, or other amendments inside the initial scope a tender that origin of an adjustment to the initial contract duration or awarded cost of contract" [1]. Another author defined change as the variance in what was designed and what in fact implemented [2]. Hegazy et al. [3] differently summarizes the definition that variation in any modification to the guidance of contract which provided to the contractor by the owner or by owner's representative. Variation orders is another general term in construction projects should be defined. Various authors defined variation orders as official documents which are used to amend the signed agreement after it is accepted by the client or client's representative it becomes part documents of the project [4] [5] [6]. Memon et al. [7]defines variation orders as the formal signed agreement between the contract parties that represent an addition, deletion, or appraisal to the contract tender documents, also identify the deviation in contract duration and contract amount, it also define the nature of the contains work. Arain \& Pheng [8] and Halwatura et al. [9] indicated that a change orders is the formal document which is used to alter the awarded contract provided by the client to the contractor, and it became an official part of the previous documents of contract. Kurdistan general condition of contractor summarize variation order as any change in scope, quality and quantity of "works" or any part of the project thereof if it necessary or it is desirable and for that reason the "contractor" should carry out any of the following works include in variations: Increase and decrease the quantity of any items in the bill of quantity, delete any part of works, substitute and specification, quality, or item with any of the work, replacing levels position and dimension for any part of work and perform additional work if it required to complete the works [10]. This study is analysis the causes of variation orders and their effect on cost and time of projects in Sulaimani province.

\section{LITERATURE REVIEW}

In order to develop a better understanding of the research objective, an extensive review has been conducted focusing on identifying the reasons of variation orders and their effect on time and cost of projects. Diekmann et al. and Ibbs [11, 12] classified causes of variation orders into three groups; design changes, unforeseen conditions and design errors and omissions. From another principle Keane et al. and Arian et al. $[13,14]$ classified the sources of variation orders based on the contract parties into three groups and an extra source for reasons non relating to any of parties of contract, the groups were owner related causes, design consultant related causes, contractor related causes and other related causes. According to Aljeshi and Almarzou [15] change in plan by owner is the main reasons of variation orders, and also replacing materials and procedure, errors and omission in design were the most occurrence causes of variation order, authors found that contract cost overrun and contract schedule overrun were to be the most important impact of variation order on project. Another study by Ismail et al. [16] to determine five critical causes of variation orders out of twenty six causes, it was revealed that "change of plan and scope by owner, errors and omissions in design, differing site conditions and financial difficulty to the contractor" were to be the most occurrence causes of variation order in project in Iran, and also discovered that overrun in contract cost and time were the most observed effects of variation orders. Table 1 presented selected causes and effects variation order from reviewed related studies. Studies related to cost and time overrun due to variation orders, Kumaraswamy et al. [17] stated that contract schedule overrun due to change orders were $10-50 \%$ of contract duration and it participate to 6-17\% of contract cost overrun. Sunday [18] found that variation orders were contribute for time overrun between $27-68 \%$ and overrun of contract cost of between $25-78 \%$. Ismail et al. 
[16] conducted a study for five large roadway projects which completed between 2013 and 2017 was suffered from variation orders. The results of variation orders in these projects were delays from $50 \%$ to $137 \%$ from duration of original contract in some cases. Otherwise, increase in project cost to $15 \%$ from original contract value. Oyewobi et al. [19] stated that change orders have a direct impact on both schedule and cost performance in projects in Nigeria, with average time and cost escalation of 29.45 and 33.95percent, respectively, from the original project agreement. Dickson et al. [20] used a questionnaire to evaluate the impact of variations on projects in Kenya. Results showed that variations affected on time and cost overruns in rate of $32-179 \%$ and $70-151 \%$ respectively.

Table 1: Identifying causes of variation of studies in review Author/Year/Country/ Reference

\begin{tabular}{|c|c|c|c|c|c|c|c|c|c|c|c|c|c|c|c|c|}
\hline \multirow[t]{2}{*}{$\dot{z}$} & \multirow[t]{2}{*}{ Causes of variation orders } & 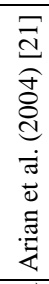 & 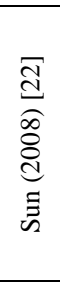 & 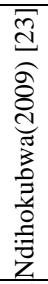 & 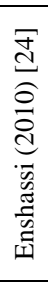 & 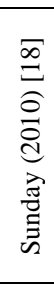 & 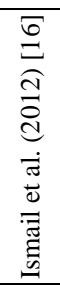 & 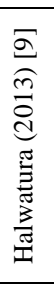 & 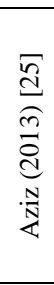 & 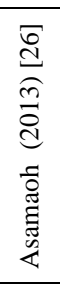 & 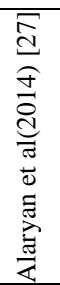 & 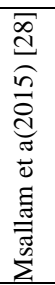 & 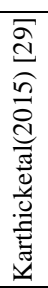 & 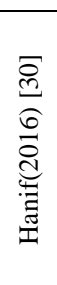 & 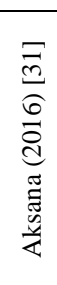 & 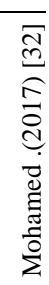 \\
\hline & & 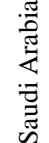 & 光 & 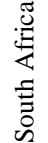 & 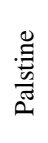 & $\begin{array}{l}\stackrel{\vartheta}{0} \\
\frac{\tilde{D}}{0} \\
\grave{d} \\
\tilde{n}\end{array}$ & 氠 & 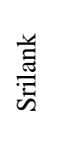 & 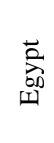 & 芯 & 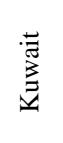 & 胥 & 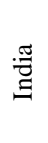 & 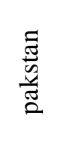 & 总 & 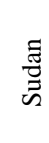 \\
\hline 1 & $\begin{array}{l}\text { Change in design by consultant during } \\
\text { construction stage }\end{array}$ & $\sqrt{ }$ & $\sqrt{ }$ & $\sqrt{ }$ & $\sqrt{ }$ & $\sqrt{ }$ & $\sqrt{ }$ & $\sqrt{ }$ & $\sqrt{ }$ & & $\sqrt{ }$ & $\sqrt{1}$ & $\sqrt{ }$ & & & \\
\hline 2 & Errors and omissions in design & $\sqrt{ }$ & $\sqrt{ }$ & $\sqrt{ }$ & $\sqrt{ }$ & $\sqrt{ }$ & $\sqrt{ }$ & $\sqrt{ }$ & & & $\sqrt{ }$ & & $\sqrt{ }$ & $\sqrt{ }$ & $\sqrt{ }$ & $\sqrt{ }$ \\
\hline 3 & Conflict between contract documents & $\sqrt{ }$ & $\sqrt{ }$ & $\sqrt{ }$ & $\sqrt{ }$ & $\sqrt{ }$ & $\sqrt{ }$ & $\sqrt{ }$ & & $\sqrt{ }$ & $\sqrt{ }$ & $\sqrt{ }$ & $\sqrt{ }$ & $\sqrt{ }$ & $\sqrt{ }$ & \\
\hline 4 & $\begin{array}{l}\text { Lack of coordination among project } \\
\text { parties in design stage }\end{array}$ & $\sqrt{ }$ & $\sqrt{ }$ & $\sqrt{ }$ & & $\sqrt{ }$ & $\sqrt{ }$ & $\sqrt{ }$ & $\sqrt{ }$ & & & $\sqrt{ }$ & $\sqrt{ }$ & & & $\sqrt{ }$ \\
\hline 5 & $\begin{array}{l}\text { Lack of consultant's knowledge due to } \\
\text { omission in Term of Reference of } \\
\text { project }\end{array}$ & & $\sqrt{ }$ & $\sqrt{ }$ & & $\sqrt{ }$ & & & & & & & & & $\sqrt{ }$ & \\
\hline 6 & Design complexity & & & & & $\sqrt{ }$ & & $\sqrt{ }$ & & $\sqrt{ }$ & & & & & & \\
\hline 7 & Time limitation in the design phase & & & & $\sqrt{ }$ & & & & & & & & $\sqrt{ }$ & & & \\
\hline 8 & Inadequate working drawing details & $\sqrt{ }$ & & $\sqrt{ }$ & & $\sqrt{ }$ & & & & $\sqrt{ }$ & $\sqrt{ }$ & & $\sqrt{ }$ & & & \\
\hline 9 & Change in plan and scope by owner & & $\sqrt{ }$ & $\sqrt{ }$ & $\sqrt{ }$ & $\sqrt{ }$ & $\sqrt{ }$ & $\sqrt{ }$ & $\sqrt{ }$ & $\sqrt{ }$ & $\sqrt{ }$ & $\sqrt{ }$ & $\sqrt{ }$ & $\sqrt{ }$ & $\sqrt{ }$ & \\
\hline 10 & Owner's financial difficulties & $\sqrt{ }$ & & $\sqrt{ }$ & $\sqrt{ }$ & $\sqrt{ }$ & $\sqrt{ }$ & & & $\sqrt{1}$ & $\sqrt{ }$ & $\sqrt{ }$ & $\sqrt{ }$ & $\sqrt{ }$ & $\sqrt{ }$ & \\
\hline 11 & $\begin{array}{l}\text { Change in specification of materials and } \\
\text { procedure by owner }\end{array}$ & $\sqrt{ }$ & & $\sqrt{ }$ & $\sqrt{ }$ & $\sqrt{ }$ & & & & $\sqrt{ }$ & $\sqrt{ }$ & & $\sqrt{ }$ & $\sqrt{ }$ & & \\
\hline 12 & Inadequate experience of owner's staff & & & & $\sqrt{ }$ & & & & & & & & $\sqrt{ }$ & & & \\
\hline 13 & $\begin{array}{l}\text { Owner fails to make decision at right } \\
\text { time }\end{array}$ & & & $\sqrt{ }$ & & & & & & & & & & & & \\
\hline 14 & Owner instruct to modification to design & & & & & & & & $\sqrt{ }$ & & & & $\sqrt{ }$ & & & \\
\hline 15 & $\begin{array}{l}\text { Lack of appropriate site before design } \\
\text { stage to construct of project }\end{array}$ & & & & $\sqrt{ }$ & & & & & & & & & & & \\
\hline 16 & Differing site conditions. & & & & & $\sqrt{ }$ & $\sqrt{ }$ & $\sqrt{ }$ & & $\sqrt{ }$ & & & $\sqrt{ }$ & & & \\
\hline 17 & $\begin{array}{l}\text { Failure of the contractor to provide the } \\
\text { required material from outsourcing }\end{array}$ & & & $\sqrt{ }$ & $\sqrt{ }$ & $\sqrt{ }$ & $\sqrt{ }$ & $\sqrt{ }$ & & $\sqrt{ }$ & $\sqrt{ }$ & & $\sqrt{ }$ & & & \\
\hline 18 & $\begin{array}{l}\text { Lack of specialized construction } \\
\text { manager }\end{array}$ & & $\sqrt{ }$ & & & & & & $\sqrt{ }$ & & & & $\sqrt{ }$ & & & \\
\hline 19 & $\begin{array}{l}\text { Misunderstanding of contract } \\
\text { documents during cost estimate stage }\end{array}$ & & & $\sqrt{1}$ & & & & & & & & & & & & \\
\hline 20 & $\begin{array}{l}\text { Lack of contractor's involvement in } \\
\text { design }\end{array}$ & $\sqrt{ }$ & & & & & & $\sqrt{ }$ & & $\sqrt{ }$ & & & $\sqrt{ }$ & & & \\
\hline 21 & Contractor's lack of required data & & $\sqrt{ }$ & & & $\sqrt{ }$ & & & & & & & & & & \\
\hline 22 & Contractor's desired profitability & & & & $\sqrt{ }$ & $\sqrt{ }$ & & $\sqrt{ }$ & & $\sqrt{ }$ & & & $\sqrt{ }$ & & & $\sqrt{ }$ \\
\hline
\end{tabular}




\begin{tabular}{|c|c|c|c|c|c|c|c|c|c|c|c|c|}
\hline 23 & Financial problems of the contractor & & $\sqrt{ }$ & $\sqrt{ }$ & $\sqrt{ }$ & $\sqrt{ }$ & & & $\sqrt{ }$ & & & \\
\hline 24 & Changes in the BoQ of work & & & & & & & & & & & $\sqrt{ }$ \\
\hline 25 & Weather conditions & $\sqrt{ }$ & $\sqrt{ }$ & $\sqrt{ }$ & $\sqrt{ }$ & & $\sqrt{ }$ & $\sqrt{ }$ & $\sqrt{ }$ & & $\sqrt{ }$ & \\
\hline 26 & Safety consideration & $\sqrt{ }$ & $\sqrt{ }$ & $\sqrt{ }$ & & $\sqrt{ }$ & & $\sqrt{ }$ & $\sqrt{ }$ & $\sqrt{ }$ & $\sqrt{ }$ & \\
\hline 27 & Change in economic conditions & & $\sqrt{ }$ & $\sqrt{ }$ & & & & & & $\sqrt{ }$ & & \\
\hline 28 & Internal political problems & $\sqrt{ }$ & $\sqrt{ }$ & & & & & & & & & \\
\hline 29 & Unforeseen problems & $\sqrt{ }$ & $\sqrt{ }$ & $\sqrt{ }$ & & & & & & & & \\
\hline 30 & Change in government regulations & $\sqrt{ }$ & $\sqrt{ }$ & $\sqrt{ }$ & $\sqrt{ }$ & & $\sqrt{ }$ & $\sqrt{ }$ & $\sqrt{ }$ & $\sqrt{ }$ & $\sqrt{ }$ & $\sqrt{ }$ \\
\hline \multicolumn{13}{|c|}{ Effects of variation order on projects } \\
\hline 1 & Time overrun & $\sqrt{ }$ & $\sqrt{ }$ & $\sqrt{ }$ & $\sqrt{ }$ & & & & $\sqrt{ }$ & $\sqrt{ }$ & $\sqrt{ }$ & $\sqrt{ }$ \\
\hline 2 & Cost overrun & $\sqrt{ }$ & $\sqrt{ }$ & $\sqrt{ }$ & $\sqrt{ }$ & & & & $\sqrt{ }$ & $\sqrt{ }$ & & $\sqrt{ }$ \\
\hline 3 & Dispute between contract parties & $\sqrt{ }$ & $\sqrt{ }$ & $\sqrt{ }$ & $\sqrt{ }$ & & & & $\sqrt{ }$ & & $\sqrt{ }$ & $\sqrt{ }$ \\
\hline 4 & Delay in payment & & & $\sqrt{ }$ & & & & & $\sqrt{ }$ & $\sqrt{ }$ & $\sqrt{ }$ & $\sqrt{ }$ \\
\hline 5 & Additional specialist equipment \& staff & $\sqrt{ }$ & & & & & & & & $\sqrt{ }$ & & \\
\hline 6 & Degradation of quality standards & & $\sqrt{ }$ & $\sqrt{ }$ & $\sqrt{ }$ & & & & $\sqrt{ }$ & $\sqrt{ }$ & $\sqrt{ }$ & $\sqrt{ }$ \\
\hline 7 & Productivity degradation & $\sqrt{ }$ & & $\sqrt{ }$ & & & & & $\sqrt{ }$ & $\sqrt{ }$ & & $\sqrt{ }$ \\
\hline 8 & Rework and demolition & & & $\sqrt{ }$ & & & & & $\sqrt{ }$ & $\sqrt{ }$ & $\sqrt{ }$ & $\sqrt{ }$ \\
\hline 9 & Logistics delays (Procurement delay) & & & & & & & & & $\sqrt{ }$ & $\sqrt{ }$ & \\
\hline 10 & Additional payment for contractor & $\sqrt{ }$ & & $\sqrt{ }$ & $\sqrt{ }$ & & & & $\sqrt{ }$ & & $\sqrt{ }$ & $\sqrt{ }$ \\
\hline
\end{tabular}

\section{METHODS AND MATERIALS}

\subsection{Questionnaire Design}

A questionnaire form was designed to evaluate the point of view of owners, contractor and consultant about frequency of occurrence and effects of causes of variation orders. The questionnaire was separated into three sections. Respondents general information took part as first section. Second section was about frequency of occurrence and their effect of causes on both cost and time overrun. The causes were categorized into their sources as: owner related causes, contractor related causes, consultant related causes and other related causes. Effects of variation orders on project were the third section of the questionnaire. After questions of general information were answered, participants were asked about the potential of all causes according to their frequency of occurrence and their impact on cost and time overrun based on following Likert scale: for frequency of occurrence :Never occurrence(1), rarely occurrence(2), sometimes occurrence(3), often occurrence(4), always occurrence(5). And also, for effect scale: None effect (1), little effect (2), moderate effect (3), great effect (4), extreme effect (5) were used.

\subsection{Experimental study}

After a questionnaire designed, experimental study was conducted to make an effective survey. It can help finding the weaknesses and strengths of the questionnaire. Twelve questionnaires form were distributed to specialized construction engineers. The causes were simplified and paraphrased depending on criticism and advice from experts and specialized, therefore context of the causes developed more clearer in order to be easy for stating respondents' point of view, it can help to reach objectives of the study. Eventually, a number of causes and effects from the experimental study stage were merged, added, deleted or modified. Following opinions were summary of major views extracted from experimental study:

1. The following reasons were added to different groups: i)Lack of adequate road to reach project location; ii) Change project location after design stage or before construction stage; iii) Lack of adequate or appropriate site before design stage to construct of project; iv) Preparing typical design for difference districts; v) Corruption;

vi) MEP (Mechanical, Electrical and Plumbing), Road, sewerage and water service

2. Some causes were rearranged so as to give more appropriate and dependable meaning. 


\subsection{Method of Analysis}

The study was used mean score analysis to rank the causes and effects of variation orders based on occurrence and their effects on time and cost overrun, then average of the mean score of these three criterions to calculate the overall MS and ranking. Mean score (MS) was calculated by following formula.

Mean score $(\mathrm{MS})=\frac{\sum(\mathrm{fxS})}{\mathrm{N}}$

Where: $\mathrm{MS}=$ mean score, $\mathrm{f}=$ frequency of response for each score, $\mathrm{S}=$ score given to each factor (0 to 5), $\mathrm{N}=$ total number of responses for each factor.

Spearman correlation coefficient was used to evaluate the agreement between respondents point of view in ranking causes and effects of variations [24]. And it was calculated using the following for equation.

$r s=1-\left[\frac{6 \sum \mathrm{d}^{2}}{\mathrm{n}\left(\mathrm{n}^{2}-1\right)}\right]$

Where: $r s=$ spearman correlation coefficient, $d=$ different between MS assigned for each cause, $n=$ number of parties of rank.

In terms of reliability of the questionnaire Cronbach coefficient alpha was applied to evaluate the reliability of the questionnaire. It calculated by using following formula:

$\propto=\frac{K}{\mathrm{~K}-1} \times\left(1-\frac{\sum V i}{V \text { test }}\right)$.

Where: $\propto=$ Cronbach alpha, $K=$ number of questions, Vi variance of scores on each question, Vtest $=$ total variance of overall scores.

\subsection{Case study}

In order to examine the cost and time deviation due to variation orders, a case study for 40 projects was adopted which is constructed during 2007 to 2013 in Sulaimani governorate. one way ANOVA was used for analysis of case study.

\section{RESULTS AND DISCUSION}

\subsection{The Reliability of the Data General Information}

This Section generally design to provide respondent's general information. Table 2 shows the respondents' profile.

Table 2. Respondents general information's

\begin{tabular}{|c|c|c|}
\hline General information & Frequency & Percent $(\%)$ \\
\hline \multicolumn{3}{|c|}{ Sector Respondents Work in } \\
\hline Public Sector & 62 & 27.8 \\
\hline Private Sector & 117 & 52.5 \\
\hline Combined & 44 & 19.7 \\
\hline \multicolumn{3}{|c|}{ Parties Respondents Worked for } \\
\hline Client & 70 & 31.4 \\
\hline Consultant & 70 & 31.4 \\
\hline Contractor & 83 & 37.2 \\
\hline \multicolumn{3}{|c|}{ Respondents Specialist } \\
\hline Civil & 160 & 71.7 \\
\hline Architecture & 35 & 15.7 \\
\hline Electrical & 14 & 6.3 \\
\hline Mechanical & 14 & 6.3 \\
\hline \multicolumn{3}{|c|}{ Respondents Experience } \\
\hline$\leq 4$ years & 0 & 0 \\
\hline$(4-9)$ years & 25 & 11.2 \\
\hline$(9-14)$ years & 33 & 14.8 \\
\hline$(14-20)$ years & 45 & 20.2 \\
\hline Over 20 & 120 & 53.8 \\
\hline \multicolumn{3}{|c|}{ Max. contract amount Respondents Work in } \\
\hline Less than 1 Milliard IQD & 27 & 12.1 \\
\hline
\end{tabular}




\begin{tabular}{lcc}
\hline $\mathbf{( 1 - 5 )}$ Milliard IQD & 52 & 23.3 \\
\hline $\mathbf{( 5 - 1 0 )}$ Milliard IQD & 54 & 24.2 \\
\hline Over 10 Milliard IQD & 90 & 40.4 \\
\hline \multicolumn{2}{l}{ Respondents involvement in arranging of variation orders } \\
\hline Yes & 203 & 91 \\
\hline No & 20 & 9 \\
\hline
\end{tabular}

\subsection{Origin agents of variation orders}

As shown in Table 3 consultant with $\mathrm{MS}=3.35$ is the main origin agent of variation orders in projects in Sulaimani governorate.

Table 3. Variation orders origin agent

\begin{tabular}{lcc}
\hline Origin agent & Mean score & Ranking \\
\hline Consultant & 3.35 & 1 \\
\hline Contractor & 2.48 & 2 \\
\hline Owner & 2.1 & 3 \\
\hline End user and others & 2.07 & 4 \\
\hline
\end{tabular}

\subsection{Causes of variation orders}

The number overall causes selected based on review and experimental study were 36 causes, the analysis of the data shown in Appendix A. The top ten of causes are selected and discussed in next sections.

\subsubsection{Top ten most frequent causes of variation orders}

Table 4 shows the top ten most occurrence causes, all these ten top causes are discussed in followings:

Table 4. Top ten most frequent causes of variation orders

\begin{tabular}{lcccccccc}
\hline \multirow{2}{*}{ Causes } & \multicolumn{2}{c}{ Owner } & \multicolumn{2}{c}{ Consultant } & \multicolumn{2}{c}{ Contractor } & \multicolumn{2}{c}{ Overall } \\
\cline { 2 - 10 } & MS & Rank & MS & Rank & MS & Rank & MS & Rank \\
\hline $\begin{array}{l}\text { Preparing typical design for } \\
\text { difference districts }\end{array}$ & 3.4 & 2 & 3.5 & 2 & 3.39 & 3 & 3.43 & 1 \\
\hline Errors and omissions in design & 3.44 & 1 & 3.11 & 6 & 3.39 & 4 & 3.31 & 2 \\
\hline Owner's financial problems & 3.4 & 3 & 3.1 & 8 & 3.40 & 2 & 3.3 & 3 \\
\hline Lime limitation in design stage & 3.11 & 8 & 3.53 & 1 & 3.11 & 8 & 3.25 & 4 \\
\hline Design complexity & 3.27 & 5 & 2.9 & 18 & 3.42 & 1 & 3.2 & 6 \\
\hline Desired profitability of contractor & 3.2 & 6 & 3.16 & 5 & 3.22 & 5 & 3.19 & 5 \\
\hline Significant changes in BoQ of work & 3.13 & 7 & 3.11 & 7 & 3.22 & 6 & 3.15 & 7 \\
\hline $\begin{array}{l}\text { Change in design by consultant } \\
\text { during construction stage }\end{array}$ & 3.07 & 10 & 3.23 & 3 & 3.11 & 9 & 3.14 & 8 \\
\hline Differing site conditions. & 3.09 & 9 & 2.99 & 14 & 3.13 & 7 & 3.07 & 9 \\
\hline $\begin{array}{l}\text { Change in specification of materials } \\
\text { and procedure by owner }\end{array}$ & 3.3 & 4 & 2.9 & 17 & 3 & 12 & 3.06 & 10 \\
\hline
\end{tabular}

\subsubsection{Preparing typical design for difference districts}

Preparing typical design for difference districts is the most occurrence causes of variation order in projects in Sulaimani governorate. it was ranked first depending overall MS with 3.43. As illustrated in Table 4 the results show high level of agreement among the respondents to put it as the first most occurrence causes. It was ranked in the second order with MS $=3.4$ by the owner, ranked in the $2^{\text {nd }}$ order with $\mathrm{MS}=3.5$ by the consultant and in the third order with MS $=3.39$ by the contractor. During ten years of economic growth and infrastructure development، Kurdistan government mostly prepared a typical design and tender for the sectors of schools, preschool, police station, security station, and most of other type of building then awarded over difference districts. Because of variety of Sulaimani land most of the projects were suffered due to variation especially in the underground work such excavation, grabbing and grading it was definitely affected on project cost and duration. This 
factor was added during pretesting questionnaire by the nine respondents among all of respondents were answered pretesting questionnaire.

\subsubsection{Errors and omissions in design}

Errors and omissions in design was revealed to be the second most occurrence causes of variation orders. Although owner ranked first but by overall respondent it was ranked second with MS of 3.31. Arain et al. [21] found that errors and omissions in design is a significant causes of completion delay. This finding concludes that design errors and omissions in design are very common in projects in Sulaimani. When a project designed with inappropriate coverage of all project's aspects or with errors and omissions would affect the productivity of work and schedule of project. Errors should be corrected during the process of design if not it will arise during the. This result is inline with Mohammed, A. J. [31] who found that this cause is one of the top ten most occurrence in project in Erbil province.

\subsubsection{Owner's financial problems}

Owner's financial problem was ranked in third position with overall MS=3.3 which shows compliance with contractor, consultant and owner to order it in top ten occurrence cause of variation orders.it ranked in $3^{\text {rd }}$ position with $\mathrm{MS}=3.4$ by the owner, ranked in $8^{\text {th }}$ position with $\mathrm{MS}=3.1$ by the consultant and ranked in $2^{\text {nd }}$ position with $\mathrm{MS}=3.4$ by the contractor. Owner or government suffered from difficulties of financial situations in Kurdistan that started since 2014. The financial problem lead owner to order variations to suspend the projects due to economic crises in order to reduce the contract amount to make budget match with his financial capability and to make the project feasible.

\subsubsection{Time limitation to the design stage}

This cause ranked in fourth position with overall MS $=3.25$. It was ranked by both of owner and contractor in $8^{\text {th }}$ position with MS $=3.11$ by both of them and ranked in the first position with MS $=3.53$ by the consultant. From 2007 to 2014 due to the infrastructure development and economic growth in Kurdistan the government allocated a large amount of budget to make projects. Sometimes the local government and directories prepared design and bill of quantity in insufficient time to get their own portion of budget and local government prepared project design in limited time to avoid return remained budget to finance ministry. It leaded to make variation in projects during execution phase and also impact on project cost and project time.

\subsubsection{Design complexity and difficulty to understand}

This cause was ranked in $5^{\text {th }}$ most occurrence causes of variation orders with overall mean score being equals "3.2". Complexity of design highlights the require of involvement of skilled expertise and construction methods [8]. Meanwhile, it impacts the progress of activities of works, while simple projects are easier to execute [4]. The more complication in design, more difficulty appears and generate chances of occurring variations in project [29].

\subsubsection{Others most occurrence causes of variation orders}

"Contractor's desired profitability" was ranked in sixth order as the most occurrence factor with $\mathrm{MS}=3.19$. Variations are initiated additional work and activity for the contractor so, variations can appear as an additional monetary payment for the contractor. In Sulaimani, the contractor may eventually try to persuade the client of the project to issue positive variation orders, leading to get more financial profits for contractor. "Changes in the bill of quantities of work "was ranked in seventh order with overall $\mathrm{MS}=3.15$. A BOQ is a document which used in tendering process in the construction projects in which materials, parts, and labor (and their units and costs) are listed. Due to the inaccurate measuring the quantity of materials that require to finish the projects variation orders may arise during the construction phase. Shortage of quantity of any materials need to variation order to complete the work. The eighth most occurrence factor that cause variation orders was revealed to be the "change in design by consultant during construction stage" with overall $\mathrm{MS}=3.14$. The change in design by consultant may happen reflects to the lack of information about all structure mechanical and 
electrical information which require to reach the project objectives. The causes of recurrent change in design by consultant is may deficient time in design process. This finding is match with $\mathrm{Wu}$ et al. [33] who concluded that this cause is one of the ten most occurrence cause of variation orders in project. The ninth most occurrence cause was "differing site conditions" with $\mathrm{MS}=3.07$ according to the overall respondents' answer. During construction stage contractor often face with underground or unseen conditions which are unpredicted, it may have a major negative effect on cost and time of execution their activities and generated variations due to site condition. The results indicated that "change in specifications by owner" ordered in tenth position with $\mathrm{MS}=3.06$ based on overall feedback of respondents. In multiactivity situation like construction of project, owner my require to order a major variations and modifications in specifications an procurement activity

\subsection{Top ten factors rankings as per effect on project cost overrun}

Table 5 shows top ten most important causes per effect on cost overrun according to the overall respondents.

Table 5: Top ten factors rankings as per effect on project cost overrun

\begin{tabular}{|c|c|c|c|c|c|c|c|c|}
\hline \multirow[t]{2}{*}{ Causes } & \multicolumn{2}{|c|}{ Owner } & \multicolumn{2}{|c|}{ Consultant } & \multicolumn{2}{|c|}{ Contractor } & \multicolumn{2}{|c|}{ Overall } \\
\hline & MS & Rank & MS & Rank & MS & Rank & MS & Rank \\
\hline $\begin{array}{l}\text { Preparing typical design for } \\
\text { different district }\end{array}$ & 3.2 & 2 & 3.4 & 1 & 3.19 & 2 & 3.26 & 1 \\
\hline Errors and omission in design & 3.1 & 4 & 3.14 & 6 & 3.27 & 1 & 3.17 & 2 \\
\hline $\begin{array}{l}\text { Lack of adequate site before } \\
\text { design stage to construct of } \\
\text { project }\end{array}$ & 3.2 & 1 & 3.1 & 8 & 3.1 & 4 & 3.13 & 3 \\
\hline Desired profitability of contractor & 3.11 & 3 & 3.21 & 3 & 3.04 & 5 & 3.12 & 4 \\
\hline $\begin{array}{l}\text { Design complexity and difficulty } \\
\text { to understand }\end{array}$ & 3.09 & 5 & 2.81 & 15 & 3.16 & 3 & 3.02 & 5 \\
\hline $\begin{array}{l}\text { Change project location after } \\
\text { design stage or before } \\
\text { construction stage }\end{array}$ & 3 & 6 & 3.1 & 9 & 2.9 & 8 & 3 & 6 \\
\hline Unforeseen problems & 2.93 & 8 & 3.16 & 5 & 2.86 & 12 & 2.98 & 7 \\
\hline $\begin{array}{l}\text { Time limitation in the design } \\
\text { phase }\end{array}$ & 2.79 & 19 & 3.19 & 4 & 2.87 & 11 & 2.95 & 8 \\
\hline $\begin{array}{l}\text { Change in design by consultant } \\
\text { during construction stage }\end{array}$ & 2.91 & 9 & 2.91 & 11 & 2.94 & 7 & 2.92 & 9 \\
\hline $\begin{array}{l}\text { changes in the bill of quantities of } \\
\text { work }\end{array}$ & 2.83 & 14 & 3.14 & 7 & 2.78 & 18 & 2.92 & 10 \\
\hline
\end{tabular}

\subsection{Top ten factors rankings as per effect on project time overrun}

Table 6 shows top ten most important causes per effect on time overrun according to the overall respondents.

Table 6: Top ten factors ranking affecting on project time overrun

\begin{tabular}{llllllllll}
\hline \multicolumn{1}{c}{ Causes } & \multicolumn{2}{c}{ Owner } & \multicolumn{2}{c}{ Consultant } & \multicolumn{2}{c}{ Contractor } & \multicolumn{2}{c}{ Overall } \\
\cline { 2 - 10 } & MS & Rank & MS & Rank & MS & Rank & MS & Rank \\
\hline Owner's financial problems & 4.2 & 1 & 4.2 & 1 & 4.10 & 1 & 4.17 & 1 \\
\hline $\begin{array}{l}\text { Owner instructs modification to } \\
\text { design }\end{array}$ & 3.4 & 2 & 3.3 & 3 & 3.2 & 5 & 3.3 & 2 \\
\hline Errors and omission in design & 3.33 & 3 & 3.2 & 6 & 3.28 & 2 & 3.27 & 3 \\
\hline $\begin{array}{l}\text { Preparing typical design for } \\
\text { difference districts }\end{array}$ & 3.2 & 7 & 3.4 & 2 & 3.17 & 8 & 3.26 & 4 \\
\hline $\begin{array}{l}\text { Change in design by consultant } \\
\text { during construction stage }\end{array}$ & 3.26 & 5 & 3.14 & 8 & 3.24 & 4 & 3.21 & 5 \\
\hline $\begin{array}{l}\text { Lack of adequate or appropriate } \\
\text { site before design stage to }\end{array}$ & 3.23 & 8 & 3.1 & 10 & 3.2 & 6 & 3.18 & 6 \\
\hline
\end{tabular}




\begin{tabular}{lllllllll}
\hline construct of project & & & & & & & & \\
\hline Contractor financial problems & 3.27 & 4 & 3.07 & 12 & 3.17 & 9 & 3.17 & 7 \\
\hline $\begin{array}{l}\text { Desired profitability of } \\
\text { contractor }\end{array}$ & 3.13 & 9 & 3.04 & 13 & 3.18 & 7 & 3.12 & 8 \\
\hline $\begin{array}{l}\text { Failure of the contractor to } \\
\text { provide the required material } \\
\text { from outsourcing }\end{array}$ & 2.96 & 16 & 3.24 & 4 & 2.99 & 15 & 3.06 & 9 \\
\hline Weather conditions & & & & & & & & \\
\hline
\end{tabular}

\subsection{Ten top causes affecting cost and time (cost and time overruns)}

Table 7 shows top ten important causes based on average MS of three criterions according to the overall respondents (most effective causes).

Table 7: Top ten causes based on average mean score of occurrences, effect on cost and time

\begin{tabular}{lcccccccc}
\hline \multicolumn{1}{c}{ Causes } & \multicolumn{2}{c}{$\begin{array}{c}\text { Overall } \\
\text { occurrence }\end{array}$} & \multicolumn{2}{c}{$\begin{array}{c}\text { Overall cost } \\
\text { overun }\end{array}$} & \multicolumn{2}{c}{$\begin{array}{c}\text { Overall time } \\
\text { overrun }\end{array}$} & \multicolumn{2}{c}{$\begin{array}{c}\text { Average } \\
\text { overall }\end{array}$} \\
\cline { 2 - 10 } & MS & Rank & MS & Rank & MS & Rank & MS & Rank \\
\hline Owner's financial problems & 3.30 & 3 & 2.80 & 16 & 4.17 & 1 & 3.42 & 1 \\
\hline $\begin{array}{l}\text { Preparing typical design for } \\
\text { difference districts }\end{array}$ & 3.43 & 1 & 3.26 & 1 & 3.26 & 4 & 3.32 & 2 \\
\hline Errors and omissions in design & 3.31 & 2 & 3.17 & 2 & 3.27 & 3 & 3.25 & 3 \\
\hline $\begin{array}{l}\text { Desired profitability of } \\
\text { contractor }\end{array}$ & 3.19 & 6 & 3.12 & 4 & 3.12 & 8 & 3.14 & 4 \\
\hline $\begin{array}{l}\text { Lack of adequate or appropriate } \\
\text { site before design stage to } \\
\text { construct of project }\end{array}$ & 2.97 & 13 & 3.13 & 3 & 3.18 & 6 & 3.10 & 5 \\
\hline $\begin{array}{l}\text { Change in design by consultant } \\
\text { during construction stage }\end{array}$ & 3.14 & 8 & 2.92 & 9 & 3.21 & 5 & 3.09 & 6 \\
\hline Time limitation in design stage & 3.25 & 4 & 2.95 & 8 & 2.99 & 14 & 3.07 & 7 \\
\hline $\begin{array}{l}\text { Design complexity and difficulty } \\
\text { to understand }\end{array}$ & 3.20 & 5 & 3.02 & 5 & 2.96 & 18 & 3.06 & 8 \\
\hline $\begin{array}{l}\text { Owner instructs modification to } \\
\text { design }\end{array}$ & 2.80 & 18 & 2.83 & 13 & 3.30 & 2 & 2.98 & 9 \\
\hline Differing site conditions. & 3.07 & 9 & 2.87 & 11 & 2.98 & 16 & 2.97 & 10 \\
\hline
\end{tabular}

\subsection{Analysis frequency of occurrence of groups factors.}

several parties take part in construction project namely the majors party: contractor, consultant and owner. The study analysis based on different source of causes as follow:

\subsubsection{Occurrence of owner related causes on variation orders}

Table 8 shows MS and ranking of owner related causes, "Preparing typical design for difference districts" was the most occurrence factors. It was ranked first, according to overall with MS of 3.40. the results show high level of agreement among the contractor, consultant and owner to rank it in the $1^{\text {st }}$ most occurrence causes. "Owner financial problems" ranked in $2^{\text {nd }}$ position with overall $\mathrm{MS}=3.3$. "change in specification by owner" ranked in third order with overall $\mathrm{MS}=3.05$. owner and contractor ranked this factor in third order with $\mathrm{MS}=3.3$ and $\mathrm{MS}=3$ respectively while consultant was ranked it in sixth position with MS $=2.9$.

Table 8. MS and Ranks of the occurrence of owner-related factors on variation orders

\begin{tabular}{lccccccccc}
\hline \multicolumn{1}{c}{ Causes } & \multicolumn{2}{c}{ Owner } & Consultant & \multicolumn{2}{c}{ Contractor } & \multicolumn{2}{c}{ Overall } \\
\cline { 2 - 10 } & MS & Rank & MS & Rank & MS & Rank & MS & Rank \\
\hline $\begin{array}{l}\text { Preparing typical design for } \\
\text { difference districts }\end{array}$ & 3.4 & 2 & 3.5 & 1 & 3.39 & 1 & 3.40 & 1 \\
\hline Owner financial problems & 3.4 & 1 & 3.1 & 2 & 3.4 & 2 & 3.3 & 2 \\
\hline $\begin{array}{l}\text { Change in specification of materials } \\
\text { and procedure by owner }\end{array}$ & 3.3 & 3 & 2.9 & 6 & 3 & 3 & 3.1 & 3 \\
\hline
\end{tabular}




\begin{tabular}{llllllllll}
\hline $\begin{array}{l}\text { Lack of adequate site before design } \\
\text { stage to construct of project }\end{array}$ & 2.9 & 4 & 3.1 & 3 & 2.9 & 4 & 3 & 4 \\
\hline $\begin{array}{l}\text { Change project plan or scope by } \\
\text { owners }\end{array}$ & 2.9 & 5 & 3 & 4 & 2.8 & 5 & 2.9 & 5 \\
\hline $\begin{array}{l}\text { Owner instructs modification to } \\
\text { design }\end{array}$ & 2.8 & 6 & 2.8 & 7 & 2.8 & 6 & 2.8 & 6 \\
\hline $\begin{array}{l}\text { Fail owner in decision making at } \\
\text { write time }\end{array}$ & 2.7 & 7 & 2.6 & 8 & 2.8 & 7 & 2.7 & 7 \\
\hline $\begin{array}{l}\text { Change project location after design } \\
\text { stage or before construction stage }\end{array}$ & 2.5 & 9 & 3 & 5 & 2.5 & 9 & 2.7 & 8 \\
\hline $\begin{array}{l}\text { Inadequate experience of owner's } \\
\text { staff }\end{array}$ & 2.6 & 8 & 2.6 & 9 & 2.6 & 8 & 2.6 & 9 \\
\hline $\begin{array}{l}\text { Lack of adequate road to reach } \\
\text { project location }\end{array}$ & 2.3 & 10 & 2.3 & 10 & 2.2 & 10 & 2.3 & 10 \\
\hline
\end{tabular}

\subsubsection{Occurrence of consultant related causes on variation orders}

Table 9 shows the MS and ranking of consultant related causes. "errors and omissions in design" was revealed to be the most occurrence causes of variation orders with overall MS=3.32. Time limitation in the design phase "was ranked in second position with overall MS $=3.25$. Also, the results demonstrate an agreement between contractor and owner. The third most occurrence cause was found to be "design complexity and difficulty to understand" with overall MS of 3.19.

Table 9. MS and Ranks of the occurrence of consultant -related factors on variation orders.

\begin{tabular}{|c|c|c|c|c|c|c|c|c|}
\hline \multirow[t]{2}{*}{ Causes } & \multicolumn{2}{|c|}{ Owner } & \multicolumn{2}{|c|}{ Consultant } & \multicolumn{2}{|c|}{ Contractor } & \multicolumn{2}{|c|}{ Overall } \\
\hline & MS & Rank & MS & Rank & MS & Rank & MS & Rank \\
\hline Errors and omissions in design & 3.44 & 1 & 3.11 & 3 & 3.39 & 2 & 3.32 & 1 \\
\hline Time limitation in design stage & 3.11 & 3 & 3.53 & 1 & 3.11 & 3 & 3.25 & 2 \\
\hline Design complexity & 3.26 & 2 & 2.90 & 5 & 3.42 & 1 & 3.19 & 3 \\
\hline $\begin{array}{l}\text { Change in design by consultant } \\
\text { during construction stage }\end{array}$ & 3.07 & 4 & 3.23 & 2 & 3.11 & 3 & 3.13 & 4 \\
\hline $\begin{array}{l}\text { Lack of consultant's knowledge due } \\
\text { to omission in ToR of project }\end{array}$ & 3.00 & 5 & 3.01 & 4 & 3.08 & 5 & 3.04 & 5 \\
\hline Inadequate working drawing details & 3.00 & 5 & 2.87 & 6 & 3.01 & 6 & 2.96 & 6 \\
\hline $\begin{array}{l}\text { Lack of coordination among project } \\
\text { parties in design stage }\end{array}$ & 2.73 & 7 & 2.63 & 7 & 2.83 & 7 & 2.74 & 7 \\
\hline Conflicts among contract documents & 2.21 & 8 & 2.30 & 8 & 2.22 & 8 & 2.24 & 8 \\
\hline
\end{tabular}

\subsubsection{Occurrence if contractor related causes on variation orders}

Table 9 shows MS and ranking of contractor related causes. "Desired profitability of contractor" was ranked in first order as the most occurrence factor with MS = 3.19, according to overall respondents. There was a significant matching between respondents' point of view about this cause. "Significant change in bill of quantity" was ranked in second position as the most occurrence factor with $\mathrm{MS}=3.16$, based on average respondents. "Differing site conditions" was ranked in third most occurrence cause of variation orders with overall $\mathrm{MS}=3.07$.

Table 10: MS and Ranks of occurrence of contractor related causes on variation orders

\begin{tabular}{|c|c|c|c|c|c|c|c|c|}
\hline \multirow[t]{2}{*}{ Causes } & \multicolumn{2}{|c|}{ Owner } & \multicolumn{2}{|c|}{ Consultant } & \multicolumn{2}{|c|}{ Contractor } & \multicolumn{2}{|c|}{ Overall } \\
\hline & MS & Rank & MS & Rank & MS & Rank & MS & Rank \\
\hline Desired profitability of contractor & 3.20 & 1 & 3.16 & 2 & 3.22 & 1 & 3.19 & 1 \\
\hline $\begin{array}{l}\text { Significant changes in the bill of } \\
\text { quantities of work }\end{array}$ & 3.13 & 2 & 3.11 & 3 & 3.22 & 1 & 3.16 & 2 \\
\hline Differing site conditions. & 3.09 & 3 & 2.99 & 4 & 3.13 & 3 & 3.07 & 3 \\
\hline $\begin{array}{l}\text { Failure of the contractor to provide } \\
\text { the required material from } \\
\text { outsourcing }\end{array}$ & 2.90 & 4 & 3.17 & 1 & 2.89 & 4 & 2.98 & 4 \\
\hline
\end{tabular}




\begin{tabular}{llllllllll}
\hline Lack of expert construction manager & 2.80 & 6 & 2.90 & 6 & 2.76 & 6 & 2.82 & 5 \\
\hline Financial problems of the contractor & 2.83 & 5 & 2.66 & 9 & 2.77 & 5 & 2.75 & 6 \\
\hline $\begin{array}{l}\text { Searching for compensating costs for } \\
\text { his low prices if any }\end{array}$ & 2.56 & 7 & 2.93 & 5 & 2.59 & 7 & 2.69 & 7 \\
\hline $\begin{array}{l}\text { Misunderstanding of tender } \\
\text { documents during cost estimate stage }\end{array}$ & 2.51 & 9 & 2.77 & 8 & 2.58 & 8 & 2.62 & 8 \\
\hline $\begin{array}{l}\text { Lack of contractor's involvement in } \\
\text { design }\end{array}$ & 2.53 & 8 & 2.79 & 7 & 2.55 & 9 & 2.62 & 8 \\
\hline Contractors lack of required data & 2.29 & 10 & 2.23 & 10 & 2.39 & 10 & 2.30 & 10 \\
\hline
\end{tabular}

\subsubsection{Occurrence of other-related factors on variation orders.}

The occurrence of other related causes has been analyzed. The findings are shown in Table 11. The "Unforeseen problem" was ranked as the most occurrence factor on the variation order with mean score $\mathrm{MS}=2.8$ according to the overall respondents' answer, that means the respondents were agree on this factor, unforeseen conditions are often encounter in the construction projects, if these conditions are not properly solved, they may cause major variations in projects [5]. "Change in economic conditions" was ranked as the second most occurrence factors with $\mathrm{MS}=2.74$ according to the overall respondents. Conditions of economic in the country is the significant reason that impact on the whole construction industry and contributors, finally, this may cause the unfavorable variations to the project [4]. "Weather conditions" was ranked in $3^{\text {rd }}$ most occurrence cause of variation orders with overall $\mathrm{MS}=2.62$.

Fisk and O'Brien. [4] [5] revealed that contrary weather conditions can impact outdoor activities in projects. This factor may force the contractor to change his schedule of work and results in adjustment of contract schedule to compensate the lost time due to change in weather conditions. Furthermore, extreme weather may result in damage and the contractor will be compensated according to contract condition if it stated in it [34].

Table 11: MS and Ranks of the occurrence of other -related factors on variation orders

\begin{tabular}{lcccccccc}
\hline \multicolumn{1}{c}{ Causes } & \multicolumn{2}{c}{ Owner } & \multicolumn{2}{c}{ Consultant } & \multicolumn{2}{c}{ Contractor } & \multicolumn{2}{c}{ Overall } \\
\cline { 2 - 10 } & MS & Rank & MS & Rank & MS & Rank & MS & Rank \\
\hline Unforeseen problems & 2.7 & 2 & 3.04 & 1 & 2.67 & 2 & 2.8 & 1 \\
\hline Change in economic conditions & 2.71 & 1 & 2.8 & 3 & 2.72 & 1 & 2.74 & 2 \\
\hline Weather conditions & 2.56 & 3 & 2.76 & 4 & 2.55 & 3 & 2.62 & 3 \\
\hline MEP, Road, sewerage service & 2.5 & 4 & 2.93 & 2 & 2.41 & 5 & 2.6 & 4 \\
\hline $\begin{array}{l}\text { Change in government } \\
\text { regulations }\end{array}$ & 2.43 & 5 & 2.5 & 7 & 2.43 & 4 & 2.45 & 5 \\
\hline Corruption & & & & & & & & \\
\hline Internal political problems & 2.13 & 7 & 2.71 & 5 & 2.22 & 6 & 2.35 & 6 \\
\hline Safety consideration & 2.24 & 6 & 2.66 & 6 & 2.18 & 7 & 2.35 & 7 \\
\hline
\end{tabular}

\subsection{Analysis of effects of variation}

The third objective of this study was to investigate the effects of variation order on projects in Sulaimani province. Table 12 shows the effects and their ranks of time overruns, cost overrun, productivity degradation, dispute between contract parties and delay in payments were the five most observable effects of variations on project. Quite contrary rework and demolition were the least observable effect of variation orders. Top five effects are discussed as follow:

Table 12: MS and Ranks effects of variation orders on the projects

\begin{tabular}{lcccccccc}
\hline \multirow{2}{*}{ Effects } & \multicolumn{2}{c}{ Owner } & \multicolumn{2}{c}{ Consultant } & \multicolumn{2}{c}{ Contractor } & \multicolumn{2}{c}{ Overall } \\
\cline { 2 - 9 } & MS & Rank & MS & Rank & MS & Rank & MS & Rank \\
\hline Time overrun & 3.86 & 1 & 3.84 & 1 & 3.86 & 1 & 3.85 & 1 \\
\hline Cost overrun & 3.70 & 2 & 3.44 & 3 & 3.67 & 2 & 3.61 & 2 \\
\hline Productivity degradation & 3.09 & 4 & 3.21 & 4 & 2.94 & 5 & 3.07 & 3 \\
\hline Disputes between contract parties & 3.19 & 3 & 3.20 & 5 & 2.83 & 6 & 3.06 & 4 \\
\hline Delay in payment & 3.06 & 5 & 2.97 & 8 & 3.08 & 3 & 3.04 & 5 \\
\hline Logistics delays & 2.87 & 7 & 3.47 & 2 & 2.76 & 7 & 3.02 & 6 \\
\hline
\end{tabular}




\begin{tabular}{lcccccccc}
\hline $\begin{array}{l}\text { Additional specialist equipment \& } \\
\text { staff }\end{array}$ & 2.90 & 6 & 2.89 & 10 & 3.02 & 4 & 2.94 & 7 \\
\hline Additional payment for contractor & 2.67 & 8 & 3.03 & 7 & 2.65 & 8 & 2.78 & 8 \\
\hline Rework and demolition & 2.24 & 9 & 3.07 & 6 & 2.23 & 9 & 2.50 & 9 \\
\hline Degradation of quality standards & 1.90 & 10 & 2.91 & 9 & 1.94 & 10 & 2.23 & 10
\end{tabular}

\subsubsection{Time overrun}

The $1^{\text {st }}$ most occurrence effect of variation orders on projects in Sulaimani was revealed to be project time overruns, with MS of 3.85. The findings show perfect agreement among all respondents on the position of this effect. Variations have an impact on the order and duration of the activities in the schedule so, Bolin [35] said "if the activities on the critical of schedule or near-critical paths are affected by changes of scope, the project initial completion date may be extended unless hurrying in work is performed". This result agrees with Alaryan et al. , Mohammed, A. J. and Desai et al. [27, 31, 36] whose found that increase in duration of project was one of the top five impacts of the variation order.

\subsubsection{Cost overrun}

Cost overrun ranked in $2^{\text {nd }}$ most occurrence effect of variation orders on projects in Sulaimani governorate with overall $\mathrm{MS}=3.61$. As shown in Table 12 there is a high level of agreement among the three respondents. It not totally unpredicted for the contract amount to increase because of frequent variation orders in project. Arian and pheng [14] stated that project's total direct and indirect costs may impact by variation orders, consequently, contract cost overrun my occur due to any major addition or amendment in the design. This result inline with Mohammed, A. J. [31] who found that project cost overrun one of the most occurrence effect of variation orders in projects in Erbil governorate and orders in $1^{\text {st }}$ position.

\subsubsection{Productivity degradation}

The third most occurrence effect of variations was revealed to be the decrease in productivity, with overall MS of 3.07. There is a perfect agreement among all parties on the position of this effect. Variation is the most crucial factor in a range of factors effecting labor productivity [37].

The variation orders frequently related with disruption, so any modification and adjustment of works have an adverse effect in decreasing labor productivity [38]. Thomas and Napolitan [39] stated from their study change orders commonly lead to disruptions and it have a potential for labor degradation of productivity of work on average 30 percent of loss of productivity occur when variations being executed.

\subsubsection{Disputes between parties of contract}

The fourth most occurrence effect of variation orders in Sulaimani governorate is dispute between contracting parties with MS $=3.06$ based on overall respondents' response. It is obvious there is a significant level of match among the three parties the owner, consultant and contractor. This result matched with Mohammed, A. J. [31] who found that dispute between contract parties projects in Erbil governorate is one of the most occurrence effect of variations.

\subsubsection{Delay in payment}

Delay in payment was one of the top five most commonly occurred effects of variation order and ranked in the $5^{\text {th }}$ order with $\mathrm{MS}=3.05$ based on overall respondents. there is a relatively moderate degree of agreement among the three parties. Construction projects are extremely dependent on receipt payments made by the owner. Delays payments for a month or more are common. Delay in payments often because of variations in projects, this eventually affects payment to the contractor which also affects his overall cash flow and the payment to be made to the subcontractors and suppliers since the contractor may not pay them unless he gets payment from the client $[6,8]$. 
4.9. Comparison of top five most occurrence causes and effects of variations

Table 13: Comparison the most important factors causing variation orders

\begin{tabular}{|c|c|c|c|c|c|c|}
\hline Z & $\begin{array}{c}\text { Current } \\
\text { Study (2020) }\end{array}$ & $\begin{array}{c}\text { Amiruddin } \\
\text { Ismail (2012) }\end{array}$ & $\begin{array}{l}\text { Memon, et } \\
\text { al. (2014) }\end{array}$ & $\begin{array}{l}\text { Alaryan, et } \\
\text { al. (2014) }\end{array}$ & $\begin{array}{l}\text { Mohamed, } \\
\text { A. J. } \\
\text { (2016) }\end{array}$ & $\begin{array}{l}\text { Wali, K. I., } \\
\text { \& Saber, N. } \\
\text { I. (2019) [40] }\end{array}$ \\
\hline & Sulaimani & Iran & Malaysia & Kuwait & Erbil & Iraq \\
\hline 1 & $\begin{array}{c}\text { Financial } \\
\text { difficulty of } \\
\text { owner }\end{array}$ & $\begin{array}{l}\text { Change of } \\
\text { plan or scope } \\
\text { by owner }\end{array}$ & $\begin{array}{l}\text { Equipment } \\
\text { unavailability }\end{array}$ & $\begin{array}{l}\text { Change of } \\
\text { plan by owner }\end{array}$ & $\begin{array}{l}\text { Change in } \\
\text { bill of } \\
\text { quantity }\end{array}$ & $\begin{array}{l}\text { Poor project } \\
\text { management }\end{array}$ \\
\hline 2 & $\begin{array}{c}\text { Preparing } \\
\text { typical design } \\
\text { for difference } \\
\text { districts }\end{array}$ & $\begin{array}{l}\text { Errors and } \\
\text { omissions in } \\
\text { design }\end{array}$ & $\begin{array}{c}\text { Poor } \\
\text { workmanship }\end{array}$ & $\begin{array}{l}\text { Change of } \\
\text { scope by } \\
\text { owner }\end{array}$ & $\begin{array}{c}\text { Change of } \\
\text { plans and } \\
\text { schedule by } \\
\text { owner }\end{array}$ & $\begin{array}{l}\text { Change in } \\
\text { economic } \\
\text { conditions }\end{array}$ \\
\hline 3 & $\begin{array}{l}\text { Errors and } \\
\text { omissions in } \\
\text { design }\end{array}$ & $\begin{array}{l}\text { Differing site } \\
\text { conditions }\end{array}$ & $\begin{array}{l}\text { Complexity } \\
\text { of design }\end{array}$ & $\begin{array}{l}\text { Problems on } \\
\text { Site }\end{array}$ & $\begin{array}{l}\text { Inadequate } \\
\text { contractor } \\
\text { experience }\end{array}$ & $\begin{array}{c}\text { Lack of } \\
\text { experience of } \\
\text { contractor }\end{array}$ \\
\hline 4 & $\begin{array}{c}\text { Desired } \\
\text { profitability of } \\
\text { contractor }\end{array}$ & $\begin{array}{l}\text { Financial } \\
\text { difficulty of } \\
\text { contractor }\end{array}$ & $\begin{array}{l}\text { Change in } \\
\text { schedule by } \\
\text { owner }\end{array}$ & $\begin{array}{c}\text { Errors and } \\
\text { omissions in } \\
\text { design }\end{array}$ & $\begin{array}{l}\text { Errors and } \\
\text { omissions } \\
\text { in design } \\
\end{array}$ & $\begin{array}{l}\text { Poor cost } \\
\text { estimation. }\end{array}$ \\
\hline 5 & $\begin{array}{c}\text { Lack of } \\
\text { adequate site } \\
\text { before design } \\
\text { stage to project }\end{array}$ & $\begin{array}{l}\text { Weather } \\
\text { condition }\end{array}$ & $\begin{array}{l}\text { Decision } \\
\text { making } \\
\text { process }\end{array}$ & $\begin{array}{l}\text { Change of } \\
\text { schedule by } \\
\text { owner }\end{array}$ & $\begin{array}{c}\text { Owner's } \\
\text { financial } \\
\text { difficulties }\end{array}$ & $\begin{array}{c}\text { Quality } \\
\text { assurance/con } \\
\text { trol }\end{array}$ \\
\hline
\end{tabular}

Table 14. Comparison top five most occurrence effects of variation orders

\begin{tabular}{|c|c|c|c|c|c|}
\hline \multirow[t]{2}{*}{ No. } & $\begin{array}{l}\text { Current study } \\
(\mathbf{2 0 2 0})\end{array}$ & $\begin{array}{c}\text { Amiruddin } \\
\text { Ismail (2012) }\end{array}$ & $\begin{array}{l}\text { Memon, et al. } \\
(2014)\end{array}$ & $\begin{array}{c}\text { Alaryan, et al. } \\
(2014)\end{array}$ & $\begin{array}{l}\text { Mohammed, A. } \\
\text { J. (2016) }\end{array}$ \\
\hline & Sulaimani & Iran & Malaysia & Kuwait & Erbil \\
\hline 1 & Time overrun & $\begin{array}{c}\text { Delay in } \\
\text { completion work }\end{array}$ & $\begin{array}{c}\text { Increase project } \\
\text { cost }\end{array}$ & $\begin{array}{c}\text { Increase in } \\
\text { project amount }\end{array}$ & $\begin{array}{c}\text { Increase project } \\
\text { cost }\end{array}$ \\
\hline 2 & Cost overrun & $\begin{array}{l}\text { Increase in } \\
\text { contract cost }\end{array}$ & $\begin{array}{l}\text { Delay in } \\
\text { completion } \\
\text { work }\end{array}$ & $\begin{array}{l}\text { Delay in } \\
\text { completion } \\
\text { work }\end{array}$ & $\begin{array}{l}\text { Delay in } \\
\text { completion } \\
\text { work }\end{array}$ \\
\hline 3 & $\begin{array}{l}\text { Productivity } \\
\text { degradation }\end{array}$ & $\begin{array}{c}\text { Disputes between } \\
\text { owner and } \\
\text { contractor }\end{array}$ & Logistic delays & $\begin{array}{l}\text { Increase in } \\
\text { individual } \\
\text { activities }\end{array}$ & $\begin{array}{c}\text { Increase in } \\
\text { duration of } \\
\text { individual } \\
\text { activities }\end{array}$ \\
\hline 4 & $\begin{array}{c}\text { Dispute } \\
\text { between parties } \\
\text { to the contract }\end{array}$ & $\begin{array}{c}\text { Decrease in } \\
\text { quality }\end{array}$ & $\begin{array}{l}\text { Slower activity } \\
\text { progress }\end{array}$ & $\begin{array}{l}\text { Additional } \\
\text { money for } \\
\text { contractor }\end{array}$ & $\begin{array}{l}\text { Additional } \\
\text { money for } \\
\text { contractor }\end{array}$ \\
\hline 5 & $\begin{array}{l}\text { Delay in } \\
\text { payment }\end{array}$ & $\begin{array}{l}\text { Additional } \\
\text { revenue for } \\
\text { contractor }\end{array}$ & Causes rework & $\begin{array}{l}\text { Delay in } \\
\text { payment }\end{array}$ & $\begin{array}{c}\text { Disputes } \\
\text { between owners } \\
\text { and contractor }\end{array}$ \\
\hline
\end{tabular}

\subsection{Reliability test}

Cronbach's coefficient alpha was applied for the second and third section of questionnaire. Table 15 shows that the results for all fields were greater than 0.75 . this range is considered acceptable as it is greater than 0.7 and good results when it is between 0.7 and 0.9 . Therefore, the findings ensure the reliability of the questionnaire.

Table 15. Reliability Cronbach's Alpha

\begin{tabular}{llc}
\hline No. & Fields & Cronbach's alpha $(\mathbf{C} \boldsymbol{\alpha})$ \\
\hline $\mathbf{1}$ & Frequency of occurrence & 0.7557 \\
\hline $\mathbf{2}$ & Effect on cost overrun & 0.7814 \\
\hline $\mathbf{3}$ & Effect on time overrun & 0.7914 \\
\hline $\mathbf{4}$ & Effects of variation orders & 0.8266 \\
\hline
\end{tabular}




\subsection{Spearman rank correlation}

To ensure the validity between the respondent categories of owner, contractor and consultant were correlated or not, spearman's correlation coefficient was applied. Table 16 shows that there is relatively significant correlation between each two respondent's group in ranking causes of variation orders based on frequency of occurrence, effect on cost overrun and effect on time over run. The highest level of match for frequency occurrence ranking is between owner and contractor with a correlation coefficient 0.981 , in addition the correlation between owner and contractor for effect on cost overrun is strongly correlated with a correlation coefficient 0.968 . For effect on time overrun answers of owner and contractor correlated with highest level of agreement with a correlation coefficient 0.971 . Due to significant correlation each two respondent, the findings of the study can be reliable.

Table16: Spearman's correlation coefficient

\begin{tabular}{ccccccc}
\hline \multirow{2}{*}{ Respondents category } & \multicolumn{2}{c}{$\begin{array}{c}\text { Frequency } \\
\text { occurrence }\end{array}$} & \multicolumn{2}{c}{$\begin{array}{c}\text { Effect on cost } \\
\text { overrun }\end{array}$} & \multicolumn{2}{c}{$\begin{array}{c}\text { Effect on time } \\
\text { overrun }\end{array}$} \\
\cline { 2 - 7 } & Coefficient & P value & Coefficient & P value & Coefficient & P value \\
\hline Owner VS consultant & 0.767 & 0.000 & 0.629 & 0.000 & 0.714 & 0.000 \\
\hline Owner VS contractor & 0.981 & 0.000 & 0.968 & 0.000 & 0.971 & 0.000 \\
\hline $\begin{array}{c}\text { Consultant VS } \\
\text { contractor }\end{array}$ & 0.772 & 0.000 & 0.624 & 0.000 & 0.689 & 0.000 \\
\hline
\end{tabular}

\subsection{Case study for reliability of cost and time overrun}

In order to get reliability of cost and overrun due to variations orders in projects in Sulaimnai governorate a case study of 40 projects were taken to analysis cost and time deviation. Table 16 presents mean values of project cost and time overrun based on different type of projects along with their $\mathrm{F}$ value, $\mathrm{F}$ critical and $\mathrm{P}$ value. Cost and time overrun mean for Sewerage, school, building and road and highway projects statistically were not. P value was larger than 0.05 . Therefore, it could not be concluded, statistically, that the sample means were different.

Table 17: ANOVA findings for cost and time overrun based on project types

\begin{tabular}{|c|c|c|c|c|c|}
\hline Type of project & Unite & Mean & $\mathbf{F}$ & P value & F critical \\
\hline \multicolumn{6}{|c|}{ Project cost overrun } \\
\hline Sewerage sector & $\%$ & 18.63 & 2.567 & 0.070 & 2.866 \\
\hline School sector & $\%$ & 23.44 & & & \\
\hline Building sector & $\%$ & 29.8 & & & \\
\hline Road and highway sector & $\%$ & 15.64 & & & \\
\hline \multicolumn{6}{|c|}{ Project time overrun } \\
\hline Sewerage sector & $\%$ & 73.02 & 0.75 & 0.53 & 2.87 \\
\hline School sector & $\%$ & 48.34 & & & \\
\hline Building sector & $\%$ & 50.26 & & & \\
\hline Road and highway sector & $\%$ & 77.32 & & & \\
\hline
\end{tabular}

Table 18 shows the cost overrun because of variations in sector of sewerage in range of $8.8 \%$ and $54.6 \%$ increasing contract amount. While the cost overrun for school sector varied between $9.7 \%$ and $53.5 \%$ increasing contract amount. In building construction sector, the cost overrun varies between $16.3 \%$ and $55.4 \%$ increasing contract amount. Furthermore, cost overrun in road and highway sector differs from $8 \%$ to $22.4 \%$ increasing contract amount. Time overrun in sewerage sector varies between $13 \%$ and $210.7 \%$ of project duration. While in school sector the time overrun is between $15.8 \%$ and $112 \%$ increasing project duration. In building sector time overrun in range of $13 \%$ to $168.5 \%$. In addition, time overrun in road and highway sector due to the variation order causes varies between 11.1 and $210.3 \%$. As stated in review of related study that variation orders contribute to overrun of contract cost and time. In order to determine the average of this contribution related data were about 4 projects which completed since 2007 to 2013 . All collected project affected by overrun of completion time in range of 11.1 percent to 210.7 percent of initial duration, and also all projects affected by cost 
overrun in the range of $8 \%$ to $55.4 \%$ of contract amount. Depending on gathered data variations accounted $20 \%$ of the total cost overrun and $65.4 \%$ of the total time overrun.

Table18: The percent of cost and time deviation

\begin{tabular}{|c|c|c|c|c|c|c|c|c|c|}
\hline \multirow[t]{3}{*}{ No. } & \multirow{3}{*}{ Project Name } & \multirow{3}{*}{\multicolumn{2}{|c|}{$\begin{array}{ll} & \\
\text { Contract } & \text { Contract } \\
\text { Amount } * 10^{3} & \text { Duration } \\
\end{array}$}} & \multirow[b]{3}{*}{$\begin{array}{c}\text { Actual } \\
\text { Cost }^{*} 10^{3}\end{array}$} & \multirow[b]{3}{*}{$\begin{array}{c}\text { Actual } \\
\text { duration }\end{array}$} & \multirow{2}{*}{\multicolumn{2}{|c|}{ Cost Deviation }} & \multirow{2}{*}{\multicolumn{2}{|c|}{$\begin{array}{c}\text { Time } \\
\text { Deviation }\end{array}$}} \\
\hline & & & & & & & & & \\
\hline & & & & & & IDQ*10 $\mathbf{1 0}^{3}$ & $\%$ & Days & $\%$ \\
\hline \multicolumn{10}{|c|}{ Sewerage Sector } \\
\hline 1 & Bakrajo Sewerageproject & 1850690 & 150 & 2013455 & 303 & 162765 & 8.8 & 153 & 102 \\
\hline 2 & Zhala village water project & 71530 & 75 & 82156.207 & 90 & 10626.207 & 14.9 & 15 & 20 \\
\hline 3 & Bakrajo Pipe network & 523880 & 56 & 579008.64 & 174 & 55128.64 & 10.5 & 118 & 210.7 \\
\hline 4 & Zargata complementary & 2588708.5 & 195 & 2815385.5 & 263 & 226677 & 8.8 & 68 & 34.9 \\
\hline 5 & Bawamurad Box sewerage & 1050000 & 90 & 1309877 & 219 & 259877 & 24.8 & 129 & 143.3 \\
\hline 6 & Water pipe for Shex Abbas & 2094747.5 & 150 & 3237860 & 185 & 1143112.5 & 54.6 & 35 & 23.3 \\
\hline 7 & Azady sewerage project & 1130925 & 89 & 1301910 & 132 & 170985 & 15.1 & 43 & 48.3 \\
\hline 8 & 48 sewerage Chamchamal & 2090620 & 104 & 2294195 & 164 & 203575 & 9.7 & 60 & 57.7 \\
\hline 9 & Baxtyary sewerage project & 2387635 & 133 & 2848646.88 & 199 & 461011.88 & 19.3 & 66 & 49.6 \\
\hline 10 & Ashty sewerage project & 1175240 & 104 & 1408240 & 146 & 233000 & 19.8 & 42 & 40.4 \\
\hline \multicolumn{10}{|c|}{ School Sector } \\
\hline 1 & 27 Classroom School in Qrga & 4427926.88 & 426 & 4855745.252 & 850 & 427818.372 & 9.7 & 424 & 99.5 \\
\hline 2 & 12 Classroom in Kanigoma & 1109186 & 300 & 1322091.682 & 549 & 212905.682 & 19.2 & 249 & 83 \\
\hline 3 & 6Classroom in Gullan village & 389234 & 228 & 480932.82 & 264 & 91698.82 & 23.6 & 36 & 15.8 \\
\hline 4 & 6 Classroom School Grdygo & 346200 & 142 & 413733.6 & 181 & 67533.6 & 19.5 & 39 & 27.5 \\
\hline 5 & 12Classroom School in Kalar & 1020000 & 240 & 1131715.034 & 295 & 111715.034 & 11 & 55 & 22.9 \\
\hline 6 & 18ClassroomSchoolQularaisy & 1178932 & 300 & 1629578.8 & 408 & 450646.8 & 38.2 & 108 & 36 \\
\hline 7 & 18Classroom SchoolZargatay & 1135194 & 300 & 1311762 & 358 & 176568 & 15.6 & 58 & 19.3 \\
\hline 8 & 12Classroom in Halabjaytaza & 891975.888 & 263 & 1005020.538 & 316 & 113044.65 & 12.7 & 53 & 20.2 \\
\hline 9 & 12Classroom inNergz village & 950458 & 320 & 1459120.718 & 471 & 508662.718 & 53.5 & 151 & 47.2 \\
\hline 10 & 6 classroom school & 279000 & 117 & 366701.011 & 248 & 87701.011 & 31.4 & 131 & 112 \\
\hline \multicolumn{10}{|c|}{ Building Sector } \\
\hline 1 & Ranya Security station & 1061840 & 310 & 1407159.15 & 406 & 345319.15 & 32.5 & 96 & 31 \\
\hline 2 & Chamchamal Civilian police & 1370300 & 250 & 1607916.3 & 285 & 237616.3 & 17.3 & 35 & 14 \\
\hline 3 & Saidsadq Civilian police & 1284130 & 231 & 1496036.375 & 261 & 211906.375 & 16.5 & 30 & 13 \\
\hline 4 & Dwarf community building & 552264 & 154 & 824741 & 262 & 272477 & 49.3 & 108 & 70.1 \\
\hline 5 & Qaradagh youth center & 1325744.5 & 290 & 1694435.5 & 378 & 368691 & 27.8 & 88 & 30.3 \\
\hline 6 & Tskia Youth center & 1155488 & 320 & 1431514.471 & 390 & 276026.471 & 23.9 & 70 & 21.9 \\
\hline 7 & New governorate building & 23505300 & 420 & 27332500 & 606 & 3827199.999 & 16.3 & 186 & 44.3 \\
\hline 8 & Kalar terminal & 1181268 & 294 & 1618281.061 & 399 & 437013.061 & 37 & 105 & 35.7 \\
\hline 9 & Sulaimani passport building & 8197547 & 750 & 12736394.55 & 2014 & 4538847.55 & 55.4 & 1264 & 168.5 \\
\hline 10 & Quality control building & 4768396 & 650 & 5816373.14 & 1130 & 1047977.14 & 22 & 480 & 73.8 \\
\hline \multicolumn{10}{|c|}{ Road and Highway Sector } \\
\hline 1 & Hawari shar road and & 10143560 & 360 & 10955044.8 & 1117 & 811484.8 & 8 & 757 & 210.3 \\
\hline 2 & Sulaimani-Tasluja Road & 18121420.11 & 210 & 21436475.9 & 320 & 3315055.791 & 18.3 & 110 & 52.4 \\
\hline 3 & Penjuen main street project & 9759420.78 & 240 & 11290197.18 & 393 & 1530776.4 & 15.7 & 153 & 63.8 \\
\hline 4 & Rzgary asphalt paving & 946105 & 240 & 1126824.5 & 290 & 180719.5 & 19.1 & 50 & 20.8 \\
\hline 5 & Bepyaz road project & 317970 & 100 & 381064 & 153 & 63094 & 19.8 & 53 & 53 \\
\hline 6 & Zharawa road project & 172106 & 45 & 205459 & 67 & 33353 & 19.4 & 22 & 48.9 \\
\hline 7 & Bngrd road project & 849865.5 & 270 & 948193.5 & 300 & 98328 & 11.6 & 30 & 11.1 \\
\hline 8 & Sarchnar interchange bridge & 8646690 & 180 & 9585991.85 & 261 & 939301.85 & 10.9 & 81 & 45 \\
\hline 9 & Bakrajo Road & 3803509.5 & 150 & 4654279.2 & 450 & 850769.7 & 22.4 & 300 & 200 \\
\hline 10 & Main street industrial area & 1945430 & 140 & 2163033.673 & 235 & 217603.673 & 11.2 & 95 & 67.9 \\
\hline
\end{tabular}




\section{ConClusion}

Based on the findings of the study the following conclusions were summarized:

1. The most effective causes of variation orders in Sulaimani governorate are: Owner's financial problems, preparing typical design for difference districts, errors and omissions in design, desired profitability of contractor and lack of adequate or appropriate site before design stage to construct of project.

2. The most occurrence causes of variation orders of owner related causes are: Preparing typical design for different districts and financial difficulties of owner and the least two occurrence variation causes are lack of adequate road to reach project location and inadequate experience of owner's staff.

3 The most occurrence of variation orders related to consultant causes are: errors and omissions in design and time limitation in design stage and the least occurrence variation causes are lack of coordination among contract parties in design stage and conflicts among contract documents.

4. The most occurrence causes of variation orders related to contractor are desired profitability of contractor and significant changes in the bill of quantities of work and the least occurrence variation causes are the lack of contractor's involvement in design and searching for compensating costs for his low prices if any.

5. In view of the other related factors, the most occurrence causes of variation orders are unforeseen problems and change in economic conditions and the least occurrence factors are the internal political problems and safety consideration

6 . The effects of variations were increase in contract duration, the variations increase contract amount, productivity degradation, disputes between contract parties and delay in payment is the fifth effect of variations.

7. All studied projects being affected by cost overruns at average of $20 \%$ of initial cost. 8. Regarding the time overruns, involved all projects at an average of $65.4 \%$ of initial contract time.

\section{REFERENCE}

[1] C. W. Ibbs, "Project change management," Industry Institute Special Publication, pp. 43-1, 1994.

[2] B. W. Wambeke, S. M. Hsiang, \& M. Liu, "Causes of Variation in Construction Project Task Starting Times and Duration," Journal of Construction Engineering and Management,137(9), pp. 663-677, 2011.

[3] T. Hegazy, E. Zanaty, \& D. Grierson, "Improving design coordination for building projects," Journal of Construction Engineering and Management, 127(4), pp. 322-329, 2001.

[4] R. Fisk, Construction Project Administration, 5th edn ed., New Jersey: Prentice-Hall, Upper Saddle River, 1997.

[5] J. O'Brien, Construction Change Orders, New York, NY.: McGraw Hill, 1998.

[6] A. Al-Dubaisi, "Change orders in construction projects in Saudi Arabia," MSc dissertation, King Fahd University of Petroleum and Minerals, Dhahran, Saudi Arabia, 2000.

[7] Memon, A., Rahman, I., \& Abu Jamil, M, "Severity of Variation Order Factors in affecting Construction Project Performance," Journal of Basic and Applied Scientific Research, 4(6), pp. 19-27, 2014.

[8] Arain, F., \& Pheng, L, "How design consultants perceive causes of variation orders for institutional buildings in Singapore," Architectural Engineering and Design Management, 1(3), p. 181-196, 2005.

[9] Halwatura, R., \& Ranasinghe, N, "Causes of Variation Orders in Road Construction Projects in Sri Lanka," ISRN Construction Engineering, 2013, pp. 1-7, 2013.

[10] The ministry of planing, legal department, " Conditions of Contract for Construction for Building and Civil Engineering," p. 35, 2006.

[11] J. E. Diekmann, \& M. C. Nelson, "Construction claims: Frequency and severity," Construction Engineering Management, 111(1), pp. 74-81, 1985.

[12] C. W. Ibbs, "Quantitative impacts of project change: size, issues," Journal of Management in Engineering, 123 (3), pp. 308-311, 1997.

[13] P. Keane, B. Sertyesilisik, \& A. R. Ross, "Variations and Change Orders on Construction Projects," Journal of Legal Affairs and dispute resolution in engineering and construction, 2(2), pp. 89-96, 2010. 
[14] F. M. Arain, \& L. S. Pheng, "The potential effects of variation orders on institutional building buildings projects," Facilities, 23 (11/12), pp. 496-510, 2006.

[15] S. Al-Jishi, \& H. Al-Marzoug, "Change orders in construction projects in Saudi-Arabia," Construction Engineering and Management Department Term Paper (CEM-520 Term Paper), 2008.

[16] A. Ismail, T. Pourrostam, A. Soleymanzadeh, \& M. Ghouyounchizad, "Factors causing variation orders and their effects in roadway construction projects," Research Journal of Applied Sciences, Engineering and Technology, 4(23), pp. 4969-4972, 2012.

[17] M. M. \&. C. D. W. Kumaraswamy, "Contributors to construction delays," Construction Management \& Economics, 16(1), pp. 17-29, 1998.

[18] O. Sunday, "Impact of variation orders on public construction projects," Association of Researchers in Construction Management, pp. 101-110, 2010.

[19] L. O. Oyewobi, R. Jimoh, B. O. Ganiyu, Ganiyu, B. O., \&A. A. Shittu, "Analysis of causes and impact of variation order on educational building projects," Journal of Facilities Management, 14(2), pp. 139-164, 2016.

[20] O. D. Dickson, M. Gerryshom, \& G. Wanyona, "Variations in civil engineering construction projects in Kenya: Causes and effects," Int. J. Eng. Res. Technol, 4(2), pp. 1124-1129, 2015.

[21] F. M. Arain, S. Assaf, \& L. S. Pheng, "Causes of discrepancies between design and construction," Architectural Science Review, 47(3), pp. 237-249, 2004.

[22] M. Sun and X. Meng, "Taxonomy for change causes and," International Journal of Project Management, 27(6), p. 560-572, 2008.

[23] R. Ndihokubwayo, \& T. Haup, "Variation Orders on Construction Projects:Value-adding or Waste?," International Journal of Construction Project Management, 1(2), 2009.

[24] Enshassi, A., Arain, F., \& Al-Raee, S, "Causes of variation orders in construction projects in the Gaza Strip," Journal of Civil Engineering and Management, 16(4), pp. 540-551, 2010.

[25] R. F. Aziz, "Factors causing cost variation for constructing wastewater projects in Egypt," Alexandria Engineering Journal, 52(1), pp. 51-66, 2013.

[26] R. O. Asamaoh, \& K. Offei-Nyako, "Variation determinants in building construction: Ghanaian professionals perspective," Journal of Construction Engineering and Project Management, 3(4), pp. 20-25, 2013.

[27] A. Alaryan, A. E. Emadelbeltagi, \& M. Dawood, "Causes and effects of change orders on construction projects in Kuwait," International Journal of Engineering Research and Applications, 4(7), pp. 1-8, 2014.

[28] M. Msallam, M. Abojaradeh, B. Jrew, \& I. Zaki, "Controlling of variation orders in highway projects in Jordan," Journal of Engineering and Architecture, 3(2), pp. 95-104, 2015.

[29] R. Karthick, B. Malathi, \& C. Umarani, "Study on change order impact on project lifecycle," International Journal of Engineering Research \& Technology, 4(5), pp. 691-695, 2015.

[30] H. Hanif, M. B. Khurshid, S. M. Lindhard, \& Z. Aslam, "Impact of variation orders on time and cost in mega hydropower projects of Pakistan," Journal of Construction in Developing Countries, 21(2), p. 37, 2016.

[31] A. J. Mohammed, "A Study For The Causes Of Variation Orders In Different Sectors Of Construction Projects In Erbil Governorate From The Point Of View Of The Involved Parties," Journal of Engineering and Sustainable Development, 20(5), pp. 30-54, 2016.

[32] E. A. E. M. S. Y. \&. H. A. S. Mohammed, "Factors Causing Variation Orders In Building Projects In Khartoum State-Sudan," IJESRT INTERNATIONAL JOURNAL OF ENGINEERING SCIENCES \& RESEARCH TECHNOLOGY, 2017.

[33] Wu, C., Hsieh, T., \& Cheng, W, "Statistical analysis of causes for design change in highway construction on Taiwan," International Journal of Project Management,23, p. 554-563, 2005.

[34] S. R. Nassar, "Management of Variation Orders in Gaza Strip: Impacts and Minimization," 2017.

[35] J. M. Bolin, "Effective change order management," Long International, inc, 2017.

[36] J. N. Desai, J. Pitroda, \& J. J. Bhavasar, "Analysis of factor affecting change order in construction industry using RII method," Scientific Journal Impact Factor, 2(6), pp. 344-348, 2015.

[37] Ibbs, W., Nguyen, L. D., \& Lee, S, "Quantified impacts of project change," Journal of Professional Issues in Engineering Education and Practice, 133(1), pp. 45-52, 2007.

[38] Z. Osman, A. Omran, and C. K. Foo, "The potential effects of variation orders in construction projects," Journal of Engineering, 7(2), pp. 141-152, 2009.

[39] H. R. Thomas, \& C. L. Napolitan, "Quantitative effects of construction changes on labor productivity," Journal of Construction Engineering and Management, 121(3), pp. 290-296, 1995.

[40] W. I. Khalil, \& N. I. Saber, "An Analysis of Causes and Factors Affecting Change Orders Occurrence in 
Construction Projects in Iraq," ZANCO Journal of Pure and Applied Sciences, 31(6), pp. 1-12, 2019.

[41] A. Al-Dubaisi, "Change orders in construction projects in Saudi Arabia," MSc dissertation, King Fahd University of Petroleum and Minerals, Dhahran, Saudi Arabia., 2000.

[42] R. Jawad, R. Abdulkader, \& A. A. Ali, "Variation orders in construction projects," Journal of Engineering and Applied Sciences, 4(3), pp. 170-176, 2009.

[43] W. T. Hester, T. C. Chang, \& J. A. Kuprenas, "Construction changes and change orders: their magnitude and impact," Construction Industry Institute, 1991. 
Appendix A. Analysis of causes of variation orders based on frequency of occurrence, effect on cost overrun, effect on time overrun and average mean score

\begin{tabular}{|c|c|c|c|c|c|c|c|c|c|c|c|c|c|c|c|c|c|c|c|c|c|c|c|c|c|c|c|}
\hline \multirow{2}{*}{ No } & \multirow[b]{2}{*}{ Causes } & \multicolumn{8}{|c|}{ Frequency of occurrence } & \multicolumn{8}{|c|}{ Effect on cost overrun } & \multicolumn{8}{|c|}{ Effect on time overrun } & \multicolumn{2}{|c|}{$\begin{array}{c}\text { Average } \\
\text { mean score }\end{array}$} \\
\hline & & \multicolumn{2}{|c|}{\begin{tabular}{ll}
\multicolumn{2}{l|}{ Owner } \\
S I Rank
\end{tabular}} & \multicolumn{2}{|c|}{$\begin{array}{l}\text { Consultant } \\
\text { MS | Rank }\end{array}$} & \multicolumn{2}{|c|}{$\begin{array}{l}\text { Contractor } \\
\text { MS }\end{array}$} & \multicolumn{2}{|c|}{ Overall } & \multicolumn{2}{|c|}{ Owner } & \multicolumn{2}{|c|}{ Consultant } & \multicolumn{2}{|c|}{ Contractor } & \multicolumn{2}{|c|}{ Overall } & \multicolumn{2}{|c|}{ Owner } & \multicolumn{2}{|c|}{ Consultant } & Con & & $\frac{\mathrm{Ov}}{\mathrm{MS}}$ & rall & MS & Rank \\
\hline 1 & Owner's financial problems & 3.4 & 3 & 3.1 & 8 & 3.40 & 2 & 3.3 & 3 & 2.9 & 11 & 2.6 & 24 & 2.9 & 10 & 2.8 & 16 & 4.2 & 1 & 4.2 & 1 & 4.10 & 1 & 4.167 & 1 & 3.42 & 1 \\
\hline 2 & $\begin{array}{l}\text { Preparing typical design for difference } \\
\text { districts }\end{array}$ & 3.4 & 2 & 3.5 & 2 & 3.39 & 3 & 3.43 & 1 & 3.2 & 1 & 3.4 & 1 & 3.19 & 2 & 3.263 & 1 & 3.2 & 7 & 3.4 & 2 & 3.17 & 8 & 3.257 & 4 & 3.32 & 2 \\
\hline 3 & Errors and omissions in design & 3.44 & 1 & 3.11 & 6 & 3.39 & 4 & 3.313 & 2 & 3.1 & 4 & 3.14 & 6 & 3.27 & 1 & 3.17 & 2 & 3.33 & 3 & 3.2 & 6 & 3.28 & 2 & 3.27 & 3 & 3.25 & 3 \\
\hline 4 & Desired profitability of contractor & 3.2 & 6 & 3.16 & 5 & 3.22 & 5 & 3.19 & 6 & 3.11 & 3 & 3.21 & 3 & 3.04 & 5 & 3.12 & 4 & 3.13 & 9 & 3.04 & 13 & 3.18 & 7 & 3.117 & 8 & 3.14 & 4 \\
\hline 5 & $\begin{array}{l}\text { Lack of adequate or appropriate site before } \\
\text { design stage to construct of project }\end{array}$ & 2.9 & 13 & 3.1 & 9 & 2.9 & 13 & 2.967 & 13 & 3.2 & 2 & 3.1 & 8 & 3.1 & 4 & 3.133 & 3 & 3.23 & 8 & 3.1 & 10 & 3.2 & 6 & 3.177 & 6 & 3.10 & 5 \\
\hline 6 & $\begin{array}{l}\text { Change in design by consultant during } \\
\text { construction stage }\end{array}$ & 3.07 & 10 & 3.23 & 3 & 3.11 & 9 & 3.14 & 8 & 2.91 & 9 & 2.91 & 11 & 2.94 & 7 & 2.92 & 9 & 3.26 & 5 & 3.14 & 8 & 3.24 & 4 & 3.213 & 5 & 3.09 & 6 \\
\hline 7 & Time limitation in the design phase & 3.11 & 8 & 3.53 & 1 & 3.11 & 8 & 3.25 & 4 & 2.79 & 19 & 3.19 & 4 & 2.87 & 11 & 2.95 & 8 & 2.89 & 21 & 3.16 & 7 & 2.92 & 17 & 2.99 & 14 & 3.07 & 7 \\
\hline 8 & $\begin{array}{l}\text { Design complexity and difficulty to } \\
\text { understand }\end{array}$ & 3.27 & 5 & 2.9 & 18 & 3.42 & 1 & 3.20 & 5 & 3.09 & 5 & 2.81 & 15 & 3.16 & 3 & 3.02 & 5 & 3.21 & 6 & 2.4 & 33 & 3.27 & 3 & 2.96 & 18 & 3.06 & 8 \\
\hline 9 & Owner instructs modification to design & 2.8 & 18 & 2.8 & 21 & 2.8 & 17 & 2.8 & 18 & 2.8 & 15 & 2.9 & 12 & 2.8 & 16 & 2.833 & 13 & 3.4 & 2 & 3.3 & 3 & 3.2 & 5 & 3.3 & 2 & 2.98 & 9 \\
\hline 10 & Differing site conditions. & 3.09 & 9 & 2.99 & 14 & 3.13 & 7 & 3.07 & 9 & 2.97 & 7 & 2.67 & 21 & 2.98 & 6 & 2.873 & 11 & 3 & 15 & 2.94 & 18 & 3 & 14 & 2.98 & 16 & 2.97 & 10 \\
\hline 11 & $\begin{array}{l}\text { Failure of the contractor to provide the } \\
\text { required material from outsourcing }\end{array}$ & 2.9 & 14 & 3.17 & 4 & 2.89 & 14 & 2.987 & 12 & 2.84 & 13 & 2.89 & 14 & 2.83 & 14 & 2.853 & 12 & 2.96 & 16 & 3.24 & 4 & 2.99 & 15 & 3.063 & 9 & 2.97 & 11 \\
\hline 12 & $\begin{array}{l}\text { Significant changes in the Bill of Quantities } \\
\text { of work }\end{array}$ & 3.13 & 7 & 3.11 & 7 & 3.22 & 6 & 3.15 & 7 & 2.83 & 14 & 3.14 & 7 & 2.78 & 18 & 2.917 & 10 & 2.61 & 27 & 2.96 & 17 & 2.82 & 23 & 2.797 & 24 & 2.96 & 12 \\
\hline 13 & $\begin{array}{l}\text { Change in specification of materials and } \\
\text { procedure by owner }\end{array}$ & 3.3 & 4 & 2.9 & 17 & 3 & 12 & 3.06 & 10 & 2.9 & 10 & 2.7 & 19 & 2.9 & 9 & 2.833 & 14 & 3 & 14 & 2.9 & 20 & 2.9 & 20 & 2.933 & 20 & 2.94 & 13 \\
\hline 14 & Unforeseen problems & 2.7 & 21 & 3.04 & 10 & 2.67 & 22 & 2.803 & 17 & 2.93 & 8 & 3.16 & 5 & 2.86 & 12 & 2.983 & 7 & 3.01 & 12 & 2.96 & 15 & 3.02 & 12 & 2.997 & 13 & 2.93 & 14 \\
\hline 15 & Change project plan or scope by owners & 2.9 & 15 & 3 & 12 & 2.8 & 16 & 2.9 & 15 & 2.8 & 16 & 2.9 & 13 & 2.8 & 17 & 2.833 & 15 & 3.1 & 10 & 3 & 14 & 3 & 13 & 3.033 & 11 & 2.92 & 15 \\
\hline 16 & $\begin{array}{l}\text { Change project location after design stage or } \\
\text { before construction stage }\end{array}$ & 2.5 & 28 & 3 & 13 & 2.5 & 28 & 2.667 & 24 & 3 & 6 & 3.1 & 9 & 2.9 & 8 & 3 & 6 & 3 & 13 & 3.1 & 11 & 2.9 & 19 & 3 & 12 & 2.89 & 16 \\
\hline 17 & Financial problems of the contractor & 2.83 & 16 & 2.66 & 27 & 2.77 & 19 & 2.753 & 19 & 2.87 & 12 & 2.41 & 33 & 2.82 & 15 & 2.7 & 20 & 3.27 & 4 & 3.07 & 12 & 3.17 & 9 & 3.17 & 7 & 2.87 & 17 \\
\hline 18 & $\begin{array}{l}\text { Lack of consultant's knowledge due to } \\
\text { omission in Term of Reference of project }\end{array}$ & 3 & 11 & 3.01 & 11 & 3.08 & 10 & 3.03 & 11 & 2.69 & 20 & 2.67 & 22 & 2.75 & 20 & 2.703 & 19 & 2.84 & 22 & 2.79 & 23 & 2.87 & 22 & 2.833 & 22 & 2.86 & 18 \\
\hline 19 & Change in economic conditions & 2.71 & 20 & 2.8 & 22 & 2.72 & 21 & 2.743 & 20 & 2.57 & 23 & 3.24 & 2 & 2.57 & 23 & 2.793 & 17 & 2.91 & 19 & 3.14 & 9 & 2.92 & 18 & 2.99 & 15 & 2.84 & 19 \\
\hline 20 & $\begin{array}{l}\text { Lack of specialized construction manager } \\
\end{array}$ & 2.8 & 17 & 2.9 & 19 & 2.76 & 20 & 2.82 & 16 & 2.61 & 22 & 2.59 & 27 & 2.65 & 21 & 2.617 & 22 & 2.93 & 17 & 2.91 & 19 & 3.04 & 11 & 2.96 & 17 & 2.80 & 20 \\
\hline 21 & $\begin{array}{l}\text { Lack of coordination among project parties } \\
\text { in design stage }\end{array}$ & 2.73 & 19 & 2.63 & 29 & 2.83 & 15 & 2.73 & 21 & 2.66 & 21 & 2.6 & 26 & 2.77 & 19 & 2.677 & 21 & 3.01 & 11 & 2.77 & 25 & 3.1 & 10 & 2.96 & 19 & 2.79 & 21 \\
\hline 22 & Inadequate working drawing details & 3 & 12 & 2.87 & 20 & 3.01 & 11 & 2.96 & 14 & 2.8 & 18 & 2.6 & 25 & 2.84 & 13 & 2.747 & 18 & 2.61 & 26 & 2.37 & 35 & 2.65 & 25 & 2.543 & 29 & 2.75 & 22 \\
\hline 23 & Weather conditions & 2.56 & 25 & 2.76 & 25 & 2.55 & 27 & 2.623 & 26 & 2.41 & 28 & 2.79 & 16 & 2.46 & 27 & 2.553 & 27 & 2.91 & 18 & 3.24 & 5 & 2.96 & 16 & 3.037 & 10 & 2.74 & 23 \\
\hline 24 & $\begin{array}{l}\begin{array}{l}\text { Owner fails to make decisions at the right } \\
\text { time. }\end{array}\end{array}$ & 2.7 & 22 & 2.6 & 30 & 2.8 & 18 & 2.7 & 22 & 2.5 & 26 & 2.7 & 20 & 2.6 & 22 & 2.6 & 24 & 2.9 & 20 & 2.9 & 21 & 2.9 & 21 & 2.9 & 21 & 2.73 & 24 \\
\hline 25 & $\begin{array}{l}\text { Searching for compensating costs for his low } \\
\text { prices if any }\end{array}$ & 2.56 & 24 & 2.93 & 15 & 2.59 & 24 & 2.693 & 23 & 2.37 & 29 & 2.76 & 18 & 2.36 & 29 & 2.497 & 30 & 2.8 & 23 & 2.79 & 24 & 2.8 & 24 & 2.797 & 23 & 2.66 & 25 \\
\hline 26 & Inadequate experience of owner's staff & 2.6 & 23 & 2.6 & 31 & 2.6 & 23 & 2.6 & 29 & 2.8 & 17 & 2.5 & 30 & 2.5 & 26 & 2.6 & 25 & 2.7 & 24 & 2.7 & 27 & 2.6 & 26 & 2.667 & 26 & 2.62 & 26 \\
\hline 27 & MEP, Road, sewerage and water service & 2.5 & 29 & 2.93 & 16 & 2.41 & 30 & 2.613 & 28 & 2.54 & 25 & 2.59 & 28 & 2.41 & 28 & 2.513 & 29 & 2.63 & 25 & 2.96 & 16 & 2.54 & 27 & 2.71 & 25 & 2.61 & 27 \\
\hline 28 & $\begin{array}{l}\text { Misunderstanding of tender documents } \\
\text { during cost estimate stage }\end{array}$ & 2.51 & 27 & 2.77 & 24 & 2.58 & 25 & 2.62 & 27 & 2.5 & 27 & 2.67 & 23 & 2.57 & 24 & 2.58 & 26 & 2.47 & 29 & 2.67 & 29 & 2.54 & 28 & 2.56 & 28 & 2.59 & 28 \\
\hline 29 & Lack of contractor's involvement in design & 2.53 & 26 & 2.79 & 23 & 2.55 & 26 & 2.623 & 25 & 2.54 & 24 & 2.76 & 17 & 2.52 & 25 & 2.607 & 23 & 2.34 & 32 & 2.83 & 22 & 2.39 & 30 & 2.52 & 30 & 2.58 & 29 \\
\hline 30 & Corruption & 2.13 & 35 & 2.71 & 26 & 2.22 & 32 & 2.353 & 32 & 2.29 & 32 & 2.99 & 10 & 2.28 & 31 & 2.52 & 28 & 2.31 & 33 & 2.61 & 30 & 2.3 & 31 & 2.407 & 32 & 2.43 & 30 \\
\hline 31 & Change in government regulations & 2.43 & 30 & 2.5 & 32 & 2.43 & 29 & 2.453 & 30 & 2.29 & 31 & 2.41 & 34 & 2.25 & 32 & 2.317 & 32 & 2.36 & 31 & 2.7 & 28 & 2.29 & 33 & 2.45 & 31 & 2.41 & 31 \\
\hline 32 & Internal political problems & 2.24 & 33 & 2.66 & 28 & 2.18 & 35 & 2.36 & 31 & 2.19 & 34 & 2.5 & 31 & 2.13 & 34 & 2.273 & 33 & 2.56 & 28 & 2.74 & 26 & 2.43 & 29 & 2.577 & 27 & 2.40 & 32 \\
\hline 33 & $\begin{array}{l}\text { Lack of adequate road to reach project } \\
\text { location }\end{array}$ & 2.3 & 31 & 2.3 & 33 & 2.2 & 34 & 2.267 & 34 & 2.2 & 33 & 2.4 & 35 & 2.1 & 35 & 2.233 & 34 & 2.4 & 30 & 2.5 & 31 & 2.3 & 32 & 2.4 & 33 & 2.30 & 33 \\
\hline 34 & Contractor's lack of required data & 2.29 & 32 & 2.23 & 35 & 2.39 & 31 & 2.303 & 33 & 2.33 & 30 & 2.39 & 36 & 2.36 & 30 & 2.36 & 31 & 2.1 & 36 & 2.36 & 36 & 2.16 & 35 & 2.207 & 36 & 2.29 & 34 \\
\hline 35 & Conflicts among contract documents & 2.21 & 34 & 2.3 & 34 & 2.22 & 33 & 2.243 & 35 & 2.1 & 35 & \begin{tabular}{|l|}
2.44 \\
\end{tabular} & 32 & 2.16 & 33 & 2.233 & 35 & 2.2 & 34 & 2.4 & 34 & 2.24 & 34 & 2.28 & 34 & 2.25 & 35 \\
\hline 36 & Safety consideration & 2 & 36 & 2.23 & 36 & 1.99 & 36 & 2.073 & 36 & 1.94 & 36 & 2.51 & 29 & 1.95 & 36 & 2.133 & 36 & 2.13 & 35 & 2.49 & 32 & 2.12 & 36 & 2.247 & 35 & 2.15 & 36 \\
\hline
\end{tabular}

